\title{
Survey of canine tick-borne diseases in Lábrea, Brazilian Amazon: 'accidental' findings of Dirofilaria immitis infection
}

\author{
Pesquisa de agentes transmitidos por carrapatos em cáes de Lábrea, Amazonas: \\ achados "acidentais" de Dirofilaria immitis
}

\author{
Herbert Sousa Soares $^{1}$; Luis Marcelo Aranha Camargo ${ }^{2,3}$; Solange Maria Gennari ${ }^{1}$; Marcelo Bahia Labruna ${ }^{1 *}$
}

${ }^{1}$ Departamento de Medicina Veterinária Preventiva e Saúde Animal, Faculdade de Medicina Veterinária e Zootecnia, Universidade de São Paulo - USP, São Paulo, SP, Brasil

${ }^{2}$ Faculdades São Lucas - FSL, Porto Velho, RO, Brasil

${ }^{3}$ Departamento de Parasitologia, Instituto de Ciências Biomédicas, Universidade de São Paulo - USP, Monte Negro, RO, Brasil

Received May 20, 2014

Accepted July 25, 2014

\begin{abstract}
Blood samples were collected from 99 domestic dogs from the urban and rural areas of the Lábrea municipality, state of Amazonas, Brazil. Canine serum samples were tested by immunofluorescence assay against Rickettsia spp., which revealed that only $3.0 \%(1 / 33)$ and $7.6 \%(5 / 66)$ of the dogs from urban and rural areas, respectively, reacted positively to at least one Rickettsia species. DNA was extracted from canine blood and tested by a battery of PCR assays targeting protozoa of the genera Babesia and Hepatozoon, and bacteria of the genera Rickettsia and Ehrlichia and family Anaplasmataceae. All samples were negative in the PCR assays targeting the genera Babesia, Hepatozoon, Ehrlichia and Rickettsia. For Anaplasmataceae, 3\% (1/33) and 39.4\% (26/66) of the urban and rural dogs, respectively, yielded amplicons that generated DNA sequences 100\% identical to the corresponding sequence of Wolbachia endosymbiont of Dirofilaria immitis. Because of these results, all canine DNA samples were further tested in a PCR assay targeting filarial nematodes, which was positive for $18.2 \%(6 / 33)$ and $57.6 \%$ (38/66) urban and rural dogs, respectively. FilarialPCR products generated DNA sequences $100 \%$ identical to D. immitis. While tick-borne infections were rare in Lábrea, D. immitis infection rates were among the highest reported in South America.
\end{abstract}

Keywords: Dogs, ticks, Rickettsia, Wolbachia, Dirofilaria immitis, Amazon.

\section{Resumo}

Amostras de sangue foram coletadas de 99 cães domésticos de áreas urbana e rural do município de Lábrea, estado do Amazonas. Soros caninos foram testados pela técnica de imunofluorescência indireta contra Rickettsia spp., resultando em apenas 3,0\% (1/33) e 7,6\% (5/66) de cáes soropositivos nas áreas urbana e rural, respectivamente. DNA foi extraído do sangue canino e testado por diferentes protocolos da PCR para detecção de protozoários dos gêneros Babesia e Hepatozoon, e bactérias dos gêneros Rickettsia e Ehrlichia e da família Anaplasmataceae. Todas as amostras foram negativas nos protocolos de PCR para os gêneros Babesia, Hepatozoon, Ehrlichia e Rickettsia. Para Anaplasmataceae, 3\% (1/33) e 39,4\% (26/66) dos cães de áreas urbana e rural, respectivamente, geraram sequências de DNA 100\% idênticas ao endosimbionte Wolbachia de Dirofilaria immitis. Posteriormente, as amostras foram testadas pela PCR para nematódeos filarídeos, resultando em 18,2\% (6/33) e 57,6\% (38/66) de amostras positivas nas áreas urbana e rural, respectivamente. Os produtos geraram sequências de DNA $100 \%$ idênticas a D. immitis. Em contraste com várias outras regiôes do Brasil, infecçôes transmitidas por carrapatos foram raras em Lábrea. Por outro lado, as frequências de infecção por $D$. immitis estiveram entre as mais altas relatadas na América do Sul.

Palavras-chave: Cáes, carrapatos, Rickettsia, Wolbachia, Dirofilaria immitis, Amazônia.

\footnotetext{
*Corresponding author: Marcelo Bahia Labruna, Departamento de Medicina

Veterinária Preventiva e Saúde Animal, Faculdade de Medicina Veterinária

e Zootecnia - FMVZ, Universidade de São Paulo - USP, Av. Prof. Orlando

Marques de Paiva, 87, Cidade Universitária, CEP 05508-270, São Paulo, SP,

Brasil, e-mail: labruna@usp.br
} 


\section{Introduction}

In recent years, there has been a substantial improvement in our knowledge of tick-borne diseases among domestic dogs in Brazil. Many recent studies have shown that canine babesiosis (caused by Babesia vogeli), hepatozoonosis (caused by Hepatozoon canis), monocytic ehrlichiosis (caused by Ehrlichia canis), and anaplasmosis (caused by Anaplasma platys) are endemic in many parts of the country (RAMOS et al., 2010; SPOLIDORIO et al., 2011; VIEIRA et al., 2011; COSTA-JÚNIOR et al., 2012; SILVA et al., 2012; DEMONER et al., 2013). While $H$. canis seems to be primarily associated with ticks of the genus Amblyomma in Brazil (FORLANO et al., 2007; DEMONER et al., 2013), the other agents mentioned above have been associated with Rhipicephalus sanguineus sensu lato ticks (DANTAS-TORRES, 2008; VIEIRA et al., 2011).

A recent study described clinical illness in domestic dogs due to Rickettsia rickettsii, the agent of Rocky Mountain spotted fever (RMSF), for the first time in Brazil (LABRUNA et al., 2009). RMSF affecting humans in Brazil has been reported since the beginning of the previous century. The agent is transmitted by Amblyomma spp. ticks (LABRUNA, 2009). In fact, domestic dogs have been considered excellent sentinels for infection by R. rickettsii and other spotted fever group (SFG) Rickettsia species in southeastern Brazil (SANGIONI et al., 2005; HORTA et al., 2007; PINTER et al., 2008). In addition, canine serosurvey in different parts of Brazil have indicated that dogs are infected with different SFG-Rickettsia species, such as $R$. rickettsii, Rickettsia parkeri, or Rickettsia amblyommii, all associated with ticks (PINTER et al., 2008; SAITO et al., 2008; MELO et al., 2011; SPOLIDORIO et al., 2013; SZABÓ et al., 2013).

Comparative studies comprising dogs from urban and rural areas of Brazil have shown that urban dogs are infested almost solely by $R$. sanguineus s.l. ticks, while rural dogs are infested mainly by different Amblyomma species, and in some cases, also by $R$. sanguineus s.l. (LABRUNA et al., 2000; SZABÓ et al., 2001; COSTA et al., 2013). This scenario has resulted in B. vogeli and E. canis infection prevalence to be generally higher in urban than in rural dogs (AGUIAR et al., 2007; SPOLIDORIO et al., 2013; VIEIRA et al., 2013) because the ecologic niche of $R$. sanguineus s.l. in Brazil is typically in human dwellings (LABRUNA \& PEREIRA, 2001). On the other hand, because $H$. canis and SFG-Rickettsia spp. are primarily associated with Amblyomma spp. ticks in Brazil, the prevalence of these agents has been generally higher among rural than urban dogs (LABRUNA et al., 2007; MELO et al., 2011; O'DWYER, 2011; SPOLIDORIO et al., 2013).

Although multiple studies on canine tick-borne diseases have been conducted in Brazil, no study was conducted in the state of Amazonas, northern Brazil. Because Amazonas preserves 98\% of its Amazon forest, it bears the second lowest population density of Brazil (2.23 inhabitants/ $\mathrm{Km}^{2}$ ); its population in the year 2012 $(3,807,923$ inhabitants, with $60 \%$ living in the capital Manaus) represented less than $2 \%$ of the Brazilian population (official data available at www.ibge.gov.br). These conditions have motivated the present study, which aimed to evaluate tick-borne agents infecting domestic dogs in Lábrea, a Municipality in the southern part of the state of Amazonas.

\section{Materials and Methods}

\section{Study site}

During February 2009, domestic dogs were sampled in the urban and rural areas of Lábrea, a municipality in the southern part of the state of Amazonas. Lábrea is a large municipality, encompassing an area of $68,229 \mathrm{Km}^{2}$, with elevation varying from 61 to $75 \mathrm{~m}$. It has a population of 41,600 inhabitants (population density: 0.61 inhabitant $/ \mathrm{km}^{2}$ ), living mostly in the urban area, whereas the rural area is comprised mostly of riverine families that usually do not raise livestock, because of the scarcity of high-water level lands. The weather is typically humid equatorial, with $>2,000 \mathrm{~mm}$ annual precipitation, and mean temperature above $25^{\circ} \mathrm{C}$ through the year (SILVA et al., 2008a). Lábrea has a typical landscape of lowland Amazonian rainforest, composed mostly by Igapós (permanently flooded land, roots of vegetation always submerged) and Várzeas (higher than Igapós, land is only submerged when rivers are at their highest during the wet season); some Low Plateau (high-water level lands, never submerged) also exists, such as the urban area and the Indian villages.

\section{Sampling dogs}

A total of 99 dogs were sampled in the present study: 33 in the urban area and 66 in the rural area. Among rural dogs, 40 were owned by riverines (living on the banks of Purus River), while 26 were owned by Indians. The geographic localities of the dogs sampled are detailed in Table 1 . The 33 urban dogs were randomly sampled according to their availability in the homes that were visited in the urban area. This sample size $(n=33)$ was calculated using Epi Info 7, considering a 5,000 population size, $15 \%$ expected frequency (based on the study of Labruna et al. (2007)), 10\% confidence limits, and a 90\% confidence level. The 66 rural dogs encompassed all canine populations that were present at each of the 6 riverine communities and the 2 Indian villages during our visits. During sampling, the following dogrelated information was obtained through a questionnaire that was applied to the owner: gender, age, breed, rearing mode (restrained or free-roaming), access to forests, living place history, and tick infestation history. From each dog, blood was collected by venipuncture in two vials: one with EDTA anticoagulant and frozen at $-20^{\circ} \mathrm{C}$ until DNA extraction; and the other without EDTA, from which sera were separated by centrifugation and kept frozen until tested by serological methods. At the time of blood collection, every dog had its whole body examined for the presence of ticks. If ticks were found, they were collected and brought to the laboratory for taxonomic identification according to Onofrio et al. (2006) and Martins et al. (2010). Procedures of this work have been approved by the Animal Ethical Commission of the Faculty of Veterinary Medicine of the University of São Paulo (protocol no. 1667/2009). 


\section{Serologic analyses}

Canine serum samples were tested by immunofluorescence assay (IFA) against six Rickettsia isolates from Brazil: $R$. rickettsii strain Taiaçu, $R$. parkeri strain At24, R. bellii strain Mogi, $R$. amblyommii strain Ac37, $R$. rhipicephali strain $\mathrm{HJ} \# 5$, and $R$. felis strain Pedreira. Slides were prepared as previously described (LABRUNA et al., 2007). Each canine serum was diluted in 2-fold increments with PBS starting from the 1:64 cut-off dilution. Ten microliters of diluted serum were added to each well of the antigen slides. Slides were incubated at $37^{\circ} \mathrm{C}$ for $30 \mathrm{~min}$ in a humid chamber. The slides were rinsed once and then washed twice for 10 min per wash in PBS. Incubation of the slides was performed with fluorescein isothiocyanate-labeled goat anti-dog IgG (Sigma Diagnostics, USA) and washed as described previously. The slides were mounted with buffered glycerin under coverslips. In each slide, a serum previously shown to be nonreactive (negative control) and a known reactive serum (positive control) were tested. For each sample, the endpoint titer reaction with each of the six rickettsial antigens was determined. Slides were read in an ultraviolet microscope (Olympus BX60, Japan) at 400 magnification.

\section{Molecular analyses}

DNA was extracted from each blood sample using the DNeasy Blood \& Tissue Kit (Qiagen, Hilden, Germany), according to the manufacturer's instructions. Blood DNA samples were individually tested by a battery of PCR assays targeting protozoa of the genera Babesia, and Hepatozoon, and bacteria of the genera Rickettsia and Ehrlichia, and family Anaplasmataceae. Genus or family-specific primers are shown in Table 2. In each PCR assay, blank controls (water) and an appropriate positive control sample (DNA extracted from canine blood infected by B. vogeli, $H$. canis or E. canis, and $R$. parkeri-infected Vero cells) were run together with the canine DNA clinical samples. PCR products of the expected size for each assay were purified with ExoSAP-IT (Amersham Biosciences, USA) and sequenced in an automatic

Table 1. Geographic localities where 99 dogs were sampled in the urban and rural areas of Lábrea municipality, state of Amazonas, northern Brazil, during January 2009.

\begin{tabular}{|c|c|c|c|c|c|c|}
\hline \multirow{2}{*}{ Locality name } & \multicolumn{2}{|c|}{ Coordinates } & \multirow{2}{*}{ Living habits } & \multirow{2}{*}{ Main landscape } & \multirow{2}{*}{ Elevation (m) } & \multirow{2}{*}{$\begin{array}{c}\text { Number sampled } \\
\text { dogs }\end{array}$} \\
\hline & South & West & & & & \\
\hline Urban area & $07015^{\prime} 55^{\prime \prime}$ & 64048'08' & Urban & Low Plateau & 62 & 33 \\
\hline \multicolumn{7}{|l|}{ Rural areas* } \\
\hline Carmelitas & 07o16'51" & $64050 ’ 10 "$ & Riverine & Várzea & 56 & 3 \\
\hline Boca do Ituchi & $07^{\circ} 18^{\prime} 36^{\prime \prime}$ & $64^{\circ} 50^{\prime} 51^{\prime \prime}$ & Riverine & Várzea & 56 & 6 \\
\hline Maciari & $07^{\circ} 16^{\prime} 57^{\prime \prime}$ & $64^{\circ} 51^{\prime} 05^{\prime \prime}$ & Riverine & Várzea & 58 & 5 \\
\hline Samaúma & $07^{\circ} 18^{\prime} 50^{\prime \prime}$ & 6508'39”' & Riverine & Várzea & 60 & 6 \\
\hline Santa Rosa & $07^{\circ} 20^{\prime} 28^{\prime \prime}$ & $64^{\circ} 59^{\prime} 50^{\prime \prime}$ & Riverine & Várzea & 65 & 12 \\
\hline Bacural & $07^{\circ} 15^{\prime} 02^{\prime \prime}$ & 64'53'03”' & Riverine & Igapó & 41 & 8 \\
\hline Jarauara & $07^{\circ} 16^{\prime} 42^{\prime \prime}$ & $65^{\circ} 10^{\prime} 31^{\prime \prime}$ & Indian village & Low Plateau & 81 & 15 \\
\hline Araça & $07^{\circ} 18^{\prime} 54^{\prime \prime}$ & $64^{\circ} 55^{\prime} 56^{\prime \prime}$ & Indian Village & Low Plateau & 84 & 11 \\
\hline
\end{tabular}

*banks of Purus River. $\mathrm{m}=$ meters.

Table 2. Primers used in the present study.

\begin{tabular}{|c|c|c|c|c|c|c|}
\hline \multicolumn{2}{|c|}{ Target } & \multicolumn{2}{|c|}{ Primer sequence $\left(5^{\prime}-3^{\prime}\right)$} & \multirow{2}{*}{$\begin{array}{c}\text { Annealing } \\
\mathrm{T}\left({ }^{\circ} \mathrm{C}\right)\end{array}$} & \multirow{2}{*}{$\begin{array}{l}\text { Amplicon } \\
\text { size (nt) }\end{array}$} & \multirow{2}{*}{ Reference } \\
\hline Organisms & Gene & Forward & Reverse & & & \\
\hline Anaplasmataceae & $16 S$ rRNA & $\begin{array}{c}\text { GGTACCYA- } \\
\text { CAGAAGAAGTCC }\end{array}$ & $\begin{array}{c}\text { TGCACTCATCGTTTA- } \\
\text { CAG }\end{array}$ & 55 & 344 & Inokuma et al. (2000) \\
\hline Ehrlichia spp. & $d s b$ & $\begin{array}{l}\text { GATGATGTTTGAA- } \\
\text { GATATSAAACAAAT }\end{array}$ & $\begin{array}{c}\text { CTATTTTACTTCTTA- } \\
\text { AAGTTGATAWATC }\end{array}$ & 52 & 401 & Doyle et al. (2005) \\
\hline Ehrlichia spp. & $d s b$ & $\begin{array}{l}\text { ATTTTTAGRGATTTTC- } \\
\text { CAATACTTGG }^{*}\end{array}$ & $\begin{array}{c}\text { CTATTTTACTTCTTA- } \\
\text { AAGTTGATAWATC }^{*}\end{array}$ & 52 & 349 & Almeida et al. (2013) \\
\hline Babesia spp. & $18 \mathrm{~S}$ rRNA & $\begin{array}{l}\text { CCGTGCTAATTG- } \\
\text { TAGGGCTAATACA }\end{array}$ & $\begin{array}{l}\text { GCTTGAAACACTC- } \\
\text { TARTTTTCTCAAAG }\end{array}$ & 58 & 551 & Almeida et al. (2012) \\
\hline Hepatozoon spp. & $18 \mathrm{~S}$ rRNA & $\begin{array}{c}\text { GGTAATTCTAGAGCTA- } \\
\text { ATACATGAGC }\end{array}$ & $\begin{array}{c}\text { ACAATAAAGTAAAAAA- } \\
\text { CAYTTCAAAG }\end{array}$ & 50 & 574 & Almeida et al. (2012) \\
\hline Rickettsia spp. & $g l t A$ & $\begin{array}{c}\text { GCAAGTATCGGTGAG- } \\
\text { GATGTAAT }\end{array}$ & $\begin{array}{c}\text { GCTTCCTTA- } \\
\text { AAATTCAATAAATCAG- } \\
\text { GAT }\end{array}$ & 50 & 401 & Labruna et al. (2004) \\
\hline Filarioidea & $\operatorname{cox} 1$ & $\begin{array}{c}\text { GCTTTRTCTTTTTGG- } \\
\text { KTTACTTTT }\end{array}$ & $\begin{array}{c}\text { TAGTRTCATA- } \\
\text { AAAAGAAGTATTAAA }\end{array}$ & 50 & 370 & To et al. (2012) \\
\hline
\end{tabular}

\footnotetext{
*Used in a heminested reaction. $\mathrm{T}=$ temperature. $\mathrm{nt}=$ nucleotides.
} 
sequencer (Applied Biosystems/PerkinElmer, model ABI Prism 310 Genetic, USA) according to the manufacturer's protocol, using the same primers (forward and reverse) used for the PCR. Partial sequences obtained were submitted to Blast analysis (ALTSCHUL et al., 1990) to determine the closest similarities in GenBank.

Because the Anaplasmataceae PCR assay generated products that were $100 \%$ identical to the Wolbachia symbiont of the canine heartworm Dirofilaria immitis (see Results section), we decided to test the canine DNA samples with primers targeting the cytochrome oxidase subunit 1 gene $(\operatorname{cox} 1)$ of filarial nematodes (Table 2), as previously described (TO et al., 2012). PCR products were purified and sequenced as described above.

\section{Results}

Of the 99 sampled dogs (33 urban, 66 rural), 56 were males and 43 females. One-third of the dogs were $\leq 1$ year old, whereas two-thirds were $>1$ year old (precise age was not possible to be determined for many adult dogs, especially those living in the Indian villages). Among the 33 urban dogs, 25 were free-roaming, with free access to the streets; rarely some of them were taken to forest areas. All 66 rural dogs had free access to forest; however, only 45 had access to low plateau forest areas. All sampled dogs had lived in the site where they were sampled for at least one year or since they were born. Owners reported previous tick infestation in 23 dogs, 1 urban and 22 rural; however, ticks crawling on walls in human dwellings were never seen. Riverines were unanimous in reporting that their dogs became tick-infested especially when they visited low plateau forest areas. Our canine examinations revealed that almost all dogs were free of ticks at the time of blood collection; only 5 dogs were found infested by ticks, which included the following species: Amblyomma naponense, Amblyomma oblongoguttatum, Amblyomma ovale, and Amblyomma scalpturatum (Table 3). All these five dogs had visited low plateau forest areas in the preceding days.

Overall, sera from only $3.0 \%(1 / 33)$ and $7.6 \%(5 / 66)$ of the dogs from urban and rural areas, respectively, reacted positively to at least one Rickettsia species. The single reactive urban dog reacted solely to $R$. rhipicephali (endpoint titer 128). Among the reactive rural dogs, 1 reacted to the 6 Rickettsia species (endpoint titers varying from 128 to 512 ), 1 reacted to $R$. rickettsii, $R$. parkeri, $R$. amblyommii, and $R$. rhipicephali (endpoint titers 128 to 256), 2 reacted to $R$. rickettsii and $R$. parkeri (endpoint titers 64 to 128), and 1 reacted solely to $R$. bellii (endpoint titer 64).

Blood samples from all 99 dogs were negative in the PCR assays targeting protozoa of the genera Babesia and Hepatozoon, and bacteria of the genera Rickettsia and Ehrlichia. In the PCR targeting members of the family Anaplasmataceae, 3\% (1/33) and $39.4 \%(26 / 66)$ of the urban and rural dogs, respectively, yielded amplicons of the expected size (Table 3), which were all demonstrated by DNA-sequencing to be $100 \%$ identical (291/291-bp) to the corresponding sequence of Wolbachia endosymbiont of $D$. immitis (GenBank accession numbers AF088187, Z49261). Because of these results, all canine DNA samples were further tested in a PCR assay targeting filarial nematodes. A total of $18.2 \%(6 / 33)$ and $57.6 \%(38 / 66)$ of the urban and rural dogs, respectively, yielded amplicons of the expected size, which include all 27 dogs that were PCR-positive for Anaplasmataceae. PCR products of 4 urban and 8 rural dogs were submitted to DNA-sequencing, resulting in sequences $100 \%$ identical (321/321-bp) to a number of corresponding sequences of D. immitis in GenBank (accession numbers AM749229, EU159111, FN391553, KC107805).

GenBank nucleotide sequence accession numbers for partial sequences generated in this study are KF977877 for the $16 \mathrm{~S}$ rRNA partial sequence of Wolbachia endosymbiont of $D$. immitis, and KF977878 for the cox1 partial sequence of $D$. immitis

Table 3. Number of dogs that yielded positive results by PCR for Wolbachia endosymbiont and the filarial nematode Dirofilaria immitis, and by serology for Rickettsia spp. organisms.

\begin{tabular}{|c|c|c|c|c|c|c|}
\hline \multirow[b]{2}{*}{ Locality name } & \multirow[b]{2}{*}{ Living habits } & \multirow[b]{2}{*}{$\begin{array}{c}\text { Number sampled } \\
\text { dogs }\end{array}$} & \multirow[b]{2}{*}{$\begin{array}{l}\text { Number of tick- } \\
\text { infested dogs (\%) }\end{array}$} & \multicolumn{3}{|c|}{ Number infected dogs (\%) } \\
\hline & & & & Wolbachia sp. & $\begin{array}{c}\text { Dirofilaria } \\
\text { immitis }\end{array}$ & Rickettsia spp. \\
\hline Urban area & Urban & 33 & 0 & $1(3.0)$ & $6(18.2)$ & $1(3.0)$ \\
\hline \multicolumn{7}{|l|}{ Rural areas } \\
\hline Carmelitas & Riverine & 3 & 0 & $1(33.3)$ & $2(66.7)$ & 0 \\
\hline Boca do Ituchi & Riverine & 6 & 0 & $3(50.0)$ & $3(50.0)$ & $1(16.7)$ \\
\hline Maciari & Riverine & 5 & 0 & $1(20.0)$ & $2(40.0)$ & 0 \\
\hline Samaúma & Riverine & 6 & $1(16.7)^{\mathrm{a}}$ & $3(50.0)$ & $5(83.3)$ & 0 \\
\hline Santa Rosa & Riverine & 12 & $1(8.3)^{\mathrm{b}}$ & $4(33.3)$ & $6(50.0)$ & $2(16.7)$ \\
\hline Bacural & Riverine & 8 & 0 & $4(50.0)$ & $4(50.0)$ & 0 \\
\hline Jarauara & Indian village & 15 & $3(20.0)^{c}$ & $7(46.7)$ & $9(60.0)$ & $1(6.7)$ \\
\hline Araça & Indian Village & 11 & 0 & $3(27.3)$ & 7 (63.6) & $1(9.1)$ \\
\hline Total & & 99 & $5(5.1)$ & $27(27.3)$ & $44(44.4)$ & $6(6.1)$ \\
\hline
\end{tabular}

${ }^{A} \operatorname{dog}$ infested by A. naponense (3 nymphs), A. oblongoguttatum (4 nymphs), and A. scalpturatum (6 nymphs); ${ }^{B}$ dog infested by A. naponense (1 nymph), A. oblongoguttatum (3 males, 1 female, 1 nymph), and A. scalpturatum (3 nymphs); ${ }^{C}$ dogs infested by $A$. scalpturatum ( 4 nymphs), A. ovale (1 female), and Amblyomma sp. (13 larvae). 


\section{Discussion}

In the present study, none of the dogs sampled were found to be infected by tick-borne agents, through molecular methods. These results suggest that the Lábrea urban area and the surrounding banks of the Purus River are not endemic or have low endemicity for canine tick-borne diseases. These results largely contrast to all other regions of Brazil that have been investigated, where recent studies have indicated, by molecular methods, that a considerable proportion of the dogs was infected by $E$. canis, $A$. platys, B. vogeli, and/or $H$. canis (RAMOS et al., 2010; SPOLIDORIO et al., 2011; VIEIRA et al., 2011; COSTAJÚNIOR et al., 2012; SILVA et al., 2012; DEMONER et al., 2013). Indeed, these results are directly related to the absence of infestations by $R$. sanguineus s.l. on the dogs of the present study because this tick species is the only known vector of $E$. canis and $B$. vogeli and the possible vector of $A$. platys (DANTAS-TORRES, 2008; VIEIRA et al., 2011). In Brazil, $R$. sanguineus s.l. is typically an urban tick that depends on human dwellings for its free-living developmental stages (LABRUNA et al., 2000; LABRUNA \& PEREIRA, 2001). The absence of $R$. sanguineus in Lábrea, as shown by our canine examinations during the field study, was corroborated by the owners' reports that they have never seen ticks crawling on walls in their homes, which is a typical behavior of $R$. sanguineus s.l. engorged stages (LABRUNA \& PEREIRA, 2001). The populations of $R$. sanguineus s.l. have been considered to be widespread all over Brazil, including different urban areas of the Amazon region (LABRUNA et al., 2005; SERRA-FREIRE, 2010). For this reason, the current situation of Lábrea should be considered an exception for the occurrence of $R$. sanguineus, and consequently, for the tick-borne agents E. canis, A. platys, and $B$. vogeli. It will be interesting to perform new surveys in Lábrea in the coming years, in order to check if $R$. sanguineus s.l. (and associated diseases) has been introduced in the region.

The Amazonian region is considered to have a great diversity of ticks, which is primarily associated with its rich vertebrate fauna (ARAGÃO, 1936; LABRUNA et al., 2005). Notably, ticks were seldom observed on the dogs of the present study. It was very interesting to hear from the riverines that their dogs usually became infested by ticks when they visited low plateau forest areas. In fact, all six dogs that were found infested by Amblyomma ticks had visited low plateau forest areas. Apart from 26 dogs that lived in Indian villages, the remaining 40 rural dogs were owned by riverines that lived in the Várzea or Igapó, areas that have flooded ground during at least half of the year. Because long submersion in water is lethal for eggs and engorged stages of many tick species (SMITH, 1973; PAULA et al., 2005; CANÇADO et al., 2006), it is likely that no tick species would be able to complete a life cycle on the ground of Várzea and Igapó lands. Additionally, these areas also become less attractive for many land mammals that usually forage on low plateau areas. This physical condition certainly turns the Várzea and Igapó landscapes less suitable for ticks, reflecting in the absence of ticks on dogs that did not visit low plateau areas. This scenario was corroborated by the riverines, who reported that their dogs (and themselves; data not shown) usually get tick-infested while visiting low plateau areas, where they usually go for hunting. Low exposure to wild ticks in the present study would explain the absence of Hepatozoon-infected dogs, because this protozoan has been associated with Amblyomma spp. ticks in Brazil (FORLANO et al., 2007; DEMONER et al., 2013).

Overall, only $6.1 \%(6 / 99)$ of the sampled dogs were seroreactive to one or more Rickettsia species. Because dogs are suitable sentinels for SFG rickettsiosis (SANGIONI et al., 2005; HORTA et al., 2007), it can be inferred that the human population of Lábrea (at least among the sites sampled in the present study) is at low risk of acquiring tick-borne spotted fever rickettsiosis. Indeed, this condition is also associated with low human and canine exposure to wild ticks (genera Amblyomma and Haemaphysalis), which carry all tick-borne Rickettsia species currently known to occur in Brazil (LABRUNA et al., 2011).

While testing canine blood for Anaplasmataceae agents, we were originally searching for tick-borne agents of the genera Anaplasma and Ehrlichia. However, we only amplified Wolbachia DNA from 27 dogs. While these results were surprising at first sight, they were technically acceptable because the genus Wolbachia belongs to the family Anaplasmataceae (DUMLER et al., 2001). The Wolbachia DNA sequences generated in this study were all identical to each other, as well as $100 \%$ identical to the available sequences of the Wolbachia endosymbiont of D. immitis, the filarial agent of canine heartworm. While many filarial species have been shown to be $100 \%$ infected by Wolbachia endosymbionts, it was shown that filarial nematode and Wolbachia phylogenies are concordant; i.e., each infected filarial species has a specific Wolbachia genotype (CASIRAGHI et al., 2001). Therefore, once we observed that the Anaplasmataceae DNA sequences corresponded to the D. immitis-Wolbachia, we presumed that these dogs were infected by $D$. immitis. Then, samples were further tested by a PCR targeting filarial DNA, which indicated that $44.4 \%$ of the dogs were infected by filarial nematodes, including the 27 that were PCR-positive for Wolbachia. We randomly selected filarial DNA from 12 dogs to be DNA sequenced, which revealed that they all corresponded to $D$. immitis. Under these circumstances, the 44 filarial PCR-positive dogs were presumed to be infected with $D$. immitis.

The transmission of infective stages of D. immitis to dogs involves a number of Culicidae mosquitoes, such as Culex spp., Anopheles spp., and Aedes spp. (DANTAS-TORRES \& OTRANTO, 2013), which are abundant in the basin of the Purus River (NATAL et al., 1992). Infection by D. immitis was shown to be widespread in the study region because all sampled areas, regardless of landscape type, or being urban or rural, contained infected dogs. Interestingly, while the prevalence of infected dogs was $18.2 \%$ in the urban area, it varied from 40 to $83.3 \%$ among the rural areas (Table 3). Higher canine infection rates in rural than in urban areas were also reported in another study in the state of Amazonas, where Silva et al. (2008b) found 4.3 and $42.3 \%$ of urban and rural dogs, respectively, infected by D. immitis. Similarly to the present study, the rural dogs sampled by Silva et al. (2008b) were mostly owned by riverines; therefore, higher canine infection rates in rural than urban areas could be related to the closer proximity of large water collections because riverines' homes are typically over water during the 6-month flooding period every year. These results could also be related to 
the distinct species composition of Culicidae mosquitoes among urban and riverine communities. Interestingly, lower prevalence ( 2 to $25 \%$ ) has usually been reported in non-Amazonian sites of Brazil (ALVES et al., 1999; LABARTHE \& GUERRERO, 2005), whereas rates of 32.4-53.4\% were reported in the eastern Brazilian Amazon (GARCEZ et al., 2006; FURTADO et al., 2009). Further studies are warranted to verify the possible epidemiological conditions that make the Amazon region more favorable for higher incidence of canine heartworm infection. Finally, D. immitis has been treated as a zoonotic agent, which can induce pulmonary, subcutaneous, or ocular lesions in humans (DANTAS-TORRES \& OTRANTO, 2013). However, such zoonotic potential could be related to strain variation or vector species, conditions yet to be investigated (DANTAS-TORRES \& OTRANTO, 2013). Further studies are needed to evaluate the zoonotic potential of $D$. immitis in the Purus River region, where the human filarial parasite Mansonella ozzardi (Manson) is also prevalent (MEDEIROS et al., 2009).

\section{References}

Aguiar DM, Cavalcante GT, Pinter A, Gennari SM, Camargo LM, Labruna MB. Prevalence of Ehrlichia canis (Rickettsiales: Anaplasmataceae) in dogs and Rhipicephalus sanguineus (Acari: Ixodidae) ticks from Brazil. J Med Entomol 2007; 44(1): 126-132. http:// dx.doi.org/10.1603/0022-2585(2007)44[126:POECRA]2.0.CO;2. PMid:17294930

Almeida AP, Marcili A, Leite RC, Nieri-Bastos FA, Domingues LN, Martins JR, et al. Coxiella symbiont in the tick Ornithodoros rostratus (Acari: Argasidae). Ticks Tick Borne Dis 2012; 3(4): 203-206. http:// dx.doi.org/10.1016/j.ttbdis.2012.02.003. PMid:22480930

Almeida AP, Souza TD, Marcili A, Labruna MB. Novel Ehrlichia and Hepatozoon agents infecting the crab-eating fox (Cerdocyon thous) in southeastern Brazil. J Med Entomol 2013; 50 (3): 640-646. http://dx.doi. org/10.1603/ME12272. PMid:23802461

Altschul SF, Gish W, Miller W, Myers EW, Lipman DJ. Basic local alignment search tool. J Mol Biol 1990; 215(3): 403-410. http://dx.doi. org/10.1016/S0022-2836(05)80360-2. PMid:2231712

Alves LC, Almeida Silva LV, Faustino MA, McCall JW, Supakonderj P, Labarthe NW, et al. Survey of canine heartworm in the city of Recife, Pernambuco, Brazil. Mem Inst Oswaldo Cruz 1999; 94(5): 587-590. http://dx.doi.org/10.1590/S0074-02761999000500004. PMid: 10464398

Aragão H. Ixodidas brasileiros e de alguns paizes limitrophes. Mem Inst Oswaldo Cruz 1936; 31(4): 759-843. http://dx.doi.org/10.1590/S007402761936000400004 .

Cançado PH, Chacón SC, Piranda EM, Paula AR, Faccini JL. [The effect of immersion in distilled water on the engorged larvae and nymphs of Amblyomma dubitatum Neumann, 1899 (Acari: Ixodidae)]. Rev Bras Parasitol Vet 2006; 15(1): 17-22. PMid:16646997.

Casiraghi M, Anderson TJ, Bandi C, Bazzocchi C, Genchi C. A phylogenetic analysis of filarial nematodes: comparison with the phylogeny of Wolbachia endosymbionts. Parasitology 2001; 122(1): 93103. http://dx.doi.org/10.1017/S0031182000007149. PMid:11197770

Costa-Júnior LM, Zahler-Rinder M, Ribeiro MFB, Rembeck K, Rabelo EML, Pfister K, et al. Use of a Real Time PCR for detecting subspecies of Babesia canis. Vet Parasitol 2012; 188(1-2): 160-163. http://dx.doi. org/10.1016/j.vetpar.2012.03.015. PMid:22516643

Costa AP, Silva AB, Costa FB, Xavier GS, Martins TF, Labruna MB, et al. A survey of ectoparasites infesting urban and rural dogs of Maranhão state, Brazil. J Med Entomol 2013; 50(3): 674-678. http://dx.doi. org/10.1603/ME12243. PMid:23802466

Dantas-Torres F. Canine vector-borne diseases in Brazil. Parasit Vectors 2008; 1(1): 25. http://dx.doi.org/10.1186/1756-3305-1-25. PMid:18691408

Dantas-Torres F, Otranto D. Dirofilariosis in the Americas: a more virulent Dirofilaria immitis? Parasit Vectors 2013; 6(1): 288. http://dx.doi org/10.1186/1756-3305-6-288. PMid:24274042

Demoner LC, Rubini AS, Paduan KS, Metzger B, Paula Antunes JM, Martins TF, et al. Investigation of tick vectors of Hepatozoon canis in Brazil. Ticks Tick Borne Dis 2013; 4(6): 542-546. http://dx.doi. org/10.1016/j.ttbdis.2013.07.006. PMid:24209494

Doyle CK, Labruna MB, Breitschwerdt EB, Tang YW, Corstvet RE, Hegarty BC, et al. Detection of medically important Ehrlichia by quantitative multicolor TaqMan real-time polymerase chain reaction of the dsb gene. J Mol Diagn 2005; 7(4): 504-510. http://dx.doi. org/10.1016/S1525-1578(10)60581-8. PMid:16237220

Dumler JS, Barbet AF, Bekker CP, Dasch GA, Palmer GH, Ray $\mathrm{SC}$, et al. Reorganization of genera in the families Rickettsiaceae and Anaplasmataceae in the order Rickettsiales: unification of some species of Ehrlichia with Anaplasma, Cowdria with Ehrlichia and Ehrlichia with Neorickettsia, descriptions of six new species combinations and designation of Ehrlichia equi and 'HGE agent' as subjective synonyms of Ehrlichia phagocytophila. Int J Syst Evol Microbiol 2001; 51(6): 2145-2165. http://dx.doi.org/10.1099/00207713-51-6-2145. PMid:11760958

Forlano MD, Teixeira KR, Scofield A, Elisei C, Yotoko KS, Fernandes $\mathrm{KR}$, et al. Molecular characterization of Hepatozoon sp. from Brazilian dogs and its phylogenetic relationship with other Hepatozoon spp. Vet Parasitol 2007; 145(1-2): 21-30. http://dx.doi.org/10.1016/j. vetpar.2006.10.023. PMid:17134837

Furtado AP, Do Carmo ES, Giese EG, Vallinoto ACR, Lanfredi RM, Santos JN. Detection of dog filariasis in Marajo Island, Brazil by classical and molecular methods. Parasitol Res 2009; 105(6): 1509-1515. http:// dx.doi.org/10.1007/s00436-009-1584-9. PMid:19693539

Garcez LM, de Souza NF, Mota EF, Dickson LAJ, Abreu WU, Cavalcanti VF, et al. [Focus of canine heartworm disease in Marajó Island, North of Brazil: A risk factor for human health]. Rev Soc Bras Med Trop 2006; 39(4): 333-336. PMid:17119746.

Horta MC, Labruna MB, Pinter A, Linardi PM, Schumaker TT. Rickettsia infection in five areas of the state of São Paulo, Brazil. Mem Inst Oswaldo Cruz 2007; 102(7): 793-801. http://dx.doi.org/10.1590/ S0074-02762007000700003. PMid:18094887

Inokuma H, Raoult D, Brouqui P. Detection of Ehrlichia platys DNA in brown dog ticks (Rhipicephalus sanguineus) in Okinawa Island, Japan. J Clin Microbiol 2000; 38(11): 4219-4221. PMid:11060094.

Labarthe N, Guerrero J. Epidemiology of heartworm: what is happening in South America and Mexico? Vet Parasitol 2005; 133(2-3): 149-156. http://dx.doi.org/10.1016/j.vetpar.2005.04.006. PMid:16198820

Labruna MB. Ecology of rickettsia in South America. Ann N Y Acad Sci 2009; 1166(1): 156-166. http://dx.doi.org/10.1111/j.17496632.2009.04516.x. PMid:19538276 
Labruna MB, Pereira MC. Carrapato em cães no Brasil. Clin Vet (Milano) 2001; 6(30): 24-32.

Labruna MB, Homem VS, Heinemann MB, Ferreira JS No. Ticks (Acari: Ixodidae) associated with rural dogs in Uruará, eastern Amazon, Brazil. J Med Entomol 2000; 37(5): 774-776. http://dx.doi.org/10.1603/00222585-37.5.774. PMid:11004794

Labruna MB, Whitworth T, Horta MC, Bouyer DH, McBride JW, Pinter A, et al. Rickettsia species infecting Amblyomma cooperi ticks from an area in the state of São Paulo, Brazil, where Brazilian spotted fever is endemic. J Clin Microbiol 2004; 42(1): 90-98. http://dx.doi.org/10.1128/ JCM.42.1.90-98.2004. PMid:14715737

Labruna MB, Camargo LMA, Terassini FA, Ferreira F, Schumaker TTS, Camargo EP. Ticks (Acari: Ixodidae) from the state of Rondônia, western Amazon, Brazil. Syst Appl Acarol 2005; 10: 17-32.

Labruna MB, Horta MC, Aguiar DM, Cavalcante GT, Pinter A, Gennari SM, et al. Prevalence of Rickettsia infection in dogs from the urban and rural areas of Monte Negro municipality, western Amazon, Brazil. Vector Borne Zoonotic Dis 2007; 7(2): 249-255. http://dx.doi.org/10.1089/ vbz.2006.0621. PMid:17627445

Labruna MB, Kamakura O, Moraes-Filho J, Horta MC, Pacheco RC. Rocky Mountain spotted fever in dogs, Brazil. Emerg Infect Dis 2009; 15(3): 458-460. http://dx.doi.org/10.3201/eid1503.081227. PMid:19239764

Labruna MB, Mattar S, Nava S, Bermudez S, Venzal JM, Dolz G, et al. Rickettsiosis in Latin America, Caribbean, Spain and Portugal. Rev MVZ Córdoba 2011; 16(2): 2435-2457.

Martins TF, Onofrio VC, Barros-Battesti DM, Labruna MB. Nymphs of the genus Amblyomma (Acari: Ixodidae) of Brazil: descriptions, redescriptions, and identification key. Ticks Tick Borne Dis 2010; 1(2): 75-99. http://dx.doi.org/10.1016/j.ttbdis.2010.03.002. PMid:21771514

Medeiros JF, Py-Daniel V, Barbosa UC, Izzo TJ. Mansonella ozzardi in Brazil: prevalence of infection in riverine communities in the Purus region, in the state of Amazonas. Mem Inst Oswaldo Cruz 2009; 104(1): 74-80. http://dx.doi.org/10.1590/S0074-02762009000100012. PMid:19274380

Melo ALT, Martins TF, Horta MC, Moraes-Filho J, Pacheco RC, Labruna $\mathrm{MB}$, et al. Seroprevalence and risk factors to Ehrlichia spp. and Rickettsia spp. in dogs from the Pantanal Region of Mato Grosso State, Brazil. Ticks Tick Borne Dis 2011; 2(4): 213-218. http://dx.doi.org/10.1016/j. ttbdis.2011.09.007. PMid:22108015

Natal D, Barata JMS, Lagos CB, Rocha RM. Nota sobre culicídeos (Diptera: Culicidae) da bacia do rio Purus, Acre, Amazônia (Brasil). Rev Saude Publica 1992; 26(2): 129-131. http://dx.doi.org/10.1590/ S0034-89101992000200010. PMid:1364016

O'Dwyer LH. Brazilian canine hepatozoonosis. Rev Bras Parasitol Vet 2011; 20(3): 181-193. http://dx.doi.org/10.1590/S198429612011000300002. PMid:21961746

Onofrio VC, Labruna MB, Pinter A, Giacomin FG, Barros-Battesti DM. Comentários e chaves para as espécies do gênero Amblyomma. In: Barros-Battesti DM, Arzua M, Bechara GH, editors. Carrapatos de importância médico-veterinária da região Neotropical: Um guia ilustrado para identificação de espécies. São Paulo: Vox/ICTTD-3/Butantan; 2006. p. 53-71.

Paula A, Piranda EM, Faccini JLH, Daemon E. [The effect of immersion in distilled water on the engorged larvae and nymphs of Amblyomma cajennense (Fabricius, 1787)(Acari: Ixodidae)]. Rev Bras Parasitol Vet 2005; 14(2): 65-69. PMid:16153347.
Pinter A, Horta MC, Pacheco RC, Moraes-Filho J, Labruna MB. Serosurvey of Rickettsia spp. in dogs and humans from an endemic area for Brazilian spotted fever in the State of São Paulo, Brazil. Cad Saude Publica 2008; 24(2): 247-252. http://dx.doi.org/10.1590/S0102311X2008000200003. PMid:18278271

Ramos R, Ramos C, Araújo F, Oliveira R, Souza I, Pimentel D, et al. Molecular survey and genetic characterization of tick-borne pathogens in dogs in metropolitan Recife (north-eastern Brazil). Parasitol Res 2010; 107(5): 1115-1120. http://dx.doi.org/10.1007/s00436-010-1979-7. PMid:20680344

Saito TB, Cunha-Filho NA, Pacheco RC, Ferreira F, Pappen FG, Farias NA, et al. Canine infection by rickettsiae and ehrlichiae in southern Brazil. Am J Trop Med Hyg 2008; 79(1): 102-108. PMid:18606772.

Sangioni LA, Horta MC, Vianna MC, Gennari SM, Soares RM, Galvão MA, et al. Rickettsial infection in animals and Brazilian spotted fever endemicity. Emerg Infect Dis 2005; 11(2): 265-270. http://dx.doi. org/10.3201/eid1102.040656. PMid:15752445

Serra-Freire NM. Occurrence of ticks (Acari: Ixodidae) on human hosts, in three municipalities in the State of Pará, Brazil. Rev Bras Parasitol Vet 2010; 19(3): 141-147. http://dx.doi.org/10.1590/S198429612010000300003. PMid:20943016

Silva AEP, Angelis CF, Machado LAT, Waichaman AV. Influência da precipitação na qualidade da água do Rio Purus. Acta Amazon 2008a; 38(4): 733-742. http://dx.doi.org/10.1590/S0044-59672008000400017.

Silva AMA, Almeida KS, Sousa JJN, Freitas FLC. Dirofilariose canina no município de Coari, Amazonas, Brasil. Arch Vet Sci 2008b; 13(2): 145-150.

Silva GC, Benitez AN, Girotto A, Taroda A, Vidotto MC, Garcia JL, et al. Occurrence of Ehrlichia canis and Anaplasma platys in household dogs from northern Parana. Rev Bras Parasitol Vet 2012; 21(4): 379-385. http:// dx.doi.org/10.1590/S1984-29612012005000009. PMid:23207986

Smith MW. The ecology of Amblyomma cajennense a parasite of man and animals in Trinidad. Trans R Soc Trop Med Hyg 1973; 67(1): 36. http:// dx.doi.org/10.1016/0035-9203(73)90311-8. PMid:4777424

Spolidorio MG, Torres MM, Campos WN, Melo AL, Igarashi M, Amude AM, et al. Molecular detection of Hepatozoon canis and Babesia canis vogeli in domestic dogs from Cuiabá, Brazil. Rev Bras Parasitol Vet 2011; 20(3): 253-255. http://dx.doi.org/10.1590/S1984-29612011000300015. PMid:21961759

Spolidorio MG, Minervino AH, Valadas SY, Soares HS, Neves KA, Labruna MB, et al. Serosurvey for tick-borne diseases in dogs from the Eastern Amazon, Brazil. Rev Bras Parasitol Vet 2013; 22(2): 214-219. http://dx.doi.org/10.1590/S1984-29612013005000023. PMid:23802236

Szabó MP, Cunha TM, Pinter A, Vicentini F. Ticks (Acari: Ixodidae) associated with domestic dogs in Franca region, São Paulo, Brazil. Exp Appl Acarol 2001; 25(10-11): 909-916. http://dx.doi. org/10.1023/A:1020433003028. PMid:12455880

Szabó MP, Nieri-Bastos FA, Spolidorio MG, Martins TF, Barbieri AM, Labruna MB. In vitro isolation from Amblyomma ovale (Acari: Ixodidae) and ecological aspects of the Atlantic rainforest Rickettsia, the causative agent of a novel spotted fever rickettsiosis in Brazil. Parasitology 2013; 140(6): 719-728. http://dx.doi.org/10.1017/S0031182012002065. PMid:23363571

To KK, Wong SS, Poon RW, Trendell-Smith NJ, Ngan AH, Lam JW, et al. A novel Dirofilaria species causing human and canine infections 
in Hong Kong. J Clin Microbiol 2012; 50(11):3534-3541. http://dx.doi. org/10.1128/JCM.01590-12. PMid:22915604

Vieira RF, Biondo AW, Guimarães AM, Santos AP, Santos RP, Dutra LH, et al. Ehrlichiosis in Brazil. Rev Bras Parasitol Vet 2011; 20(1): 1-12. http://dx.doi.org/10.1590/S1984-29612011000100002. PMid:21439224
Vieira TSWJ, Vieira RFC, Nascimento DAG, Tamekuni K, Toledo RS, Chandrashekar R, et al. Serosurvey of tick-borne pathogens in dogs from urban and rural areas from Parana State, Brazil. Rev Bras Parasitol Vet 2013; 22(1): 104-109. http://dx.doi.org/10.1590/S198429612013000100019. PMid:24252955 